\title{
Immunostaining by Human Herpes Virus 8 Latent Nuclear Antigen-1 of Kaposi's sarcoma: A Potential Biomarker of Severity of Disease?
} van Bogaert LJ*

National Health Laboratory Service and University of Limpopo, Polokwane, South Africa

\begin{abstract}
Objective: To investigate the clinical relevance of scoring Kaposi's sarcoma herpes virus (KSHV) expression by Human Herpes Virus-8 (HHV-8) latency-associated nuclear antigen 1 (LANA 1) in the early (early patch and plaque) and late (nodular) stages.

Methods: We applied a combined intensity weighted histoscore and a categorized score to 235 early patch, plaque and nodular stages, and compared our results with published data.

Results: The mean individual scores were significantly lower in the early patch stage compared to the plaque and nodular stages. There was no significant difference in the mean individual scores between the plaque and nodular stage. There was a wide overlap in distribution of histoscore between the three stages.

Conclusion: Since treatment modalities are not based on the histological stage nor on the histoscore, KSHV histoscoring appears not to be a useful biomarker of the severity of the disease.
\end{abstract}

Keywords: Kaposi's sarcoma; HHV-8; LANA-1; Immunohistochemistry; Histoscore; Biomarker

Impact: KSHV score is not a potential biomarker of severity of Kaposi's sarcoma.

\section{Introduction}

Chang et al. were the first to identify herpesvirus-like DNA sequences in AIDS-associated Kaposi's sarcoma (KS) [1]. It is now well documented that the human herpes virus 8 (HHV-8) or Kaposi sarcomaassociated herpes virus (KSHV) is the causative agent of KS in all its forms (classic, epidemic, endemic, iatrogenic immunosuppression). Initially, the detection of HHV-8 DNA or messenger RNA was carried out by a polymerase chain reaction (PCR) based technique, a highly sensitive test for KSHV [2]. Arguably, it is even too sensitive for the differential diagnosis of non-KS vascular lesions, since some of them have been shown to be HHV-8 PCR positive. For this reason, HHV8 immunohistochemical expression on formalin-fixed and paraffinembedded tissue has become the gold standard for the diagnosis of KS.

Dupin et al. were the first to carry out immunohistochemistry with a monoclonal antibody directed against the HHV-8 latencyassociated nuclear antigen 1 (LANA-1) [3]. LANA-1 is a latent specific gene that promotes cell cycle progression through competition with $\mathrm{E} 2 \mathrm{~F}$ for the retinoblastoma protein $(\mathrm{pRb})$, and decreases apoptosis through interaction with p53 [4-6]. Since the early 2000s, LANA-1 immunohistochemistry has become the gold standard for the diagnosis of KS $[4,7]$.

KS progresses through subsequent stages from the early patch, through the plaque and nodular stages [8]. Earlier studies have demonstrated that this progression parallels an increasing number of HHV-8 labeled cell nuclei [2,3,5,6,9-12]. These studies involved a relatively low number of cases (between 12 and 50), perhaps too small to reach statistical significance $[3,10]$.

Traditionally and for descriptive convenience, the histological spectrum is divided into four subgroups; in reality, however, there is overlap between stages and there are no differences in the pathology of the disease in the different risk groups (i.e. classic, epidemic, endemic, iatrogenic immunosuppression). Therefore, it may be artificial to subdivide KS in early (i.e. early patch and plaque stages) and late (nodular stage) stages. Moreover, the aggressive late stage variant, the fourth subgroup, is said to be extremely rare [8].

The aim of the present study was to submit a large series of consecutive KS to a histoscore combining the staining intensity and the percentage of LANA-1 labeled cell nuclei as proposed by Cheuk et al. [10] in order to validate the method as a potential biomarker of the severity of KS.

\section{Materials and Methods}

The study was carried out at the Histopathology Department of the National Health Laboratory Service in Polokwane, Limpopo. A prospective series of 235 biopsy diagnosed KS confirmed by HHV- 8 immunostaining entered the study. The cases were collected between September 2011 and August 2012, and were studied anonymously. Ethical approval was obtained from the Polokwane/Mankweng Hospital Complex and the University of Limpopo research ethics committee.

The specimens were fixed in $10 \%$ phosphate buffered formalin and embedded in paraffin. Four micrometer $(\mu \mathrm{m})$ sections were stained with Hematoxylin and Eosin for initial diagnosis. All of the cases were routinely streptavidin-biotin-peroxidase immunostained with diaminobenzidine using a murine monoclonal antibody directed against the C-terminus of the LANA-1 molecule of HHV-8 (clone

*Corresponding author: Louis-Jacques van Bogaert, MD, PhD, D.Phil, National Health Laboratory Service and University of Limpopo, Polokwane, South Africa, Tel: +27132624339; Fax: +27132624339; E-mail: louis.vanBogaert@nhls.ac.za

Received February 26, 2013; Accepted March 29, 2013; Published April 01, 2013

Citation: van Bogaert LJ (2013) Immunostaining by Human Herpes Virus 8 Latent Nuclear Antigen-1 of Kaposi's sarcoma: A Potential Biomarker of Severity of Disease? J Mol Biomark Diagn S5: 002. doi:10.4172/2155-9929.S5-002

Copyright: $\odot 2013$ van Bogaert LJ. This is an open-access article distributed under the terms of the Creative Commons Attribution License, which permits unrestricted use, distribution, and reproduction in any medium, provided the original author and source are credited 
13b10; Novocastra, New Castle upon Tyne, UK). The dilution was of 1:100. The incubation time was 30 minutes at room temperature.

The subdivision into early, plaque, and nodular stages is based on their mode of progression [9]. Early patch stage is diagnosed by the presence of scattered dilated irregular or angulated lymphaticlike spaces lined by delicate, bland endothelial cells. A diagnosis of plaque stage is reached in the presence of a band of spindle cells, slitlike vascular spaces and interstitial hemorrhages. The nodular stage is characterized by nodules (instead of plaques) of spindle cells mixed with vascular spaces [8]. Our material comprised 101 early stages, 47 plaque, and 87 nodular stages.

A semi-quantitative histoscore was implemented combining staining intensity ( 1 , weak; 2 , moderate; 3 , strong) and the percentage of labeled nuclei $(1,1-25 \% ; 2,26-50 \% ; 3,51-75 \% ; 4,76-100 \%)$, as proposed by Cheuk et al. [10]. We also counted the number of stained nuclei per high power field $(\mathrm{HPF} 10 \times 40)$.

Statistical analysis was carried out with the GraphPad software from Prism (San Diego, CA). Column statistics, Student's $t$ test, and $95 \%$ confidence intervals of proportions were used. The level of statistical significance was set at $p<0.05$.

\section{Results}

There were $101(43.0 \%)$ early patch, $47(20.0 \%)$ plaque, and 87 (37.0\%) nodular stages. Table 1 shows the mean scores of four individual parameters for the early patch, plaque, and nodular. The individual scores and total score of early patch stages were significantly lower than corresponding scores of plaque stages. The only statistically significant difference between nodular and plaque stages was the percentage of stained nuclei per high power field $(p=0.042)$.

Table 2 illustrates the distribution of the total histoscore by stage. There was an overlap of histoscore of the different stages since all stages were represented in each of the categories. There was a trend towards lower scores $(<4)$ in the early patch stage $(80 / 101$, or $79.2 \%)$ and a weak but inconclusive trend towards higher scores $(>5)$ in the plaque $(24 / 47$, or $51.0 \%)$ and nodular (52/87, or $59.8 \%)$ stage.

\section{Discussion}

From the time of the first description of KS the condition has been shrouded in ambiguity. Interestingly, Moritz Kohn, who described the first classic cases, dropped his surname to adopt the name Kaposi after his birthplace in Hungary, Kaposivar on the Kapos River [13]. Since then the condition has kept its original qualification (i.e. sarcoma) although certain current writers call it a disease, a lesion, a potentially life-threatening neoplasm, or cancer [13-18]. Others hold the view that it is unclear whether $\mathrm{KS}$ is a reactive process or a true malignant neoplasm $[8,19]$. The qualifiers attributed to KS vary from "a highly vascularised tumour-like lesion" to "a vasoformative tumour of uncertain origin and complex pathogenesis" [5,6,20,21].

Although KSHV is recognized as the causative agent of all types of KS, the natural history of classical and endemic KS differs significantly from the AIDS-related epidemic KS. The cell of origin has been widely investigated; most studies have suggested a vascular endothelial, a lymphatic endothelial, a precursor endothelial cells, or a dermal dendrocyte $[3,5,6,14,19,21,22]$. A lymphatic endothelial precursor cell origin is most likely [5].

Both LANA-1 and lymphatic marker D2-40 expression have been reported to increase with tumour progression [12,22]. Therefore, it has been suggested that they could be used as tissue biomarkers in defining patients with a higher risk of disease progression [11]. According to Dupin et al. [3], LANA-1 is expressed respectively in $<10$, up to 50 , and $>90 \%$ of spindle cells in early patch, plaque, and nodular stages respectively. Cheuk et al. [10] found 10-20\% LANA-1 expression in the early stages (early patch and plaque), and $70-80 \%$ in the late nodular stage; however, they did not assess the statistical significance of the distribution of the respective scores by stage nor did they comment on the possible usefulness of their semi-quantitative scoring system as a potential biomarker of severity of the disease. Our statistical evaluation of their cases showed no difference between the scores for early patch and plaque stages $(t=0.1 ; p=0.90)$. Our data showed no difference in histoscore between the nodular and the plaque stages.

It has been shown that the prognostic determinants of AIDS-KS are tumour extension and systemic disease [16]. Patients with AIDSKS have more opportunistic infections and higher mortality rates, but lower median viral loads than endemic KS $[23,24]$. Therefore, one could speculate that the high LANA-1 histoscore in nodular stage KS does not as such express a poor prognosis.

Treatment of KS is systemic in disseminated disease, and local for focal single or few lesions [25-27]. Although highly active antiretroviral therapy (HAART) has reduced the incidence of AIDS-KS, only half of the cases achieve resolution; moreover, HAART and other therapies (i.e. radiotherapy and chemotherapy) do not prevent new KS lesions from developing [28]. Prognostic indexes for AIDS-associated KS in the era of HAART have used having KS as the AIDS-defining illness,

\begin{tabular}{|c|c|c|c|c|c|c|c|}
\hline \multirow{2}{*}{ Parameter } & \multirow{2}{*}{$\begin{array}{l}\text { Early patch } \\
\qquad n=101\end{array}$} & \multirow{2}{*}{$\begin{array}{c}\text { Plaque } \\
n=47\end{array}$} & \multicolumn{2}{|c|}{ Early vs. plaque } & \multirow{2}{*}{$\begin{array}{c}\text { Nodular } \\
n=87\end{array}$} & \multicolumn{2}{|c|}{ Nodular vs. plaque } \\
\hline & & & $t$ & $p$ & & $t$ & $p$ \\
\hline $\mathrm{Nb}$ stained nuclei/HPF & $41.6(63.4)[18.0]^{*}$ & $162.0(221.4)[72.5]$ & 5.0 & $<0.0001$ & $232.5(228.1)[170.0]$ & 1.7 & 0.087 \\
\hline$\%$ stained nuclei/HPF & $21(22.2)[10.0]$ & $37.9(30.2)[40.0]$ & 5.0 & $<0.0001$ & $49.0(29.6)[50.0]$ & 2.1 & 0.042 \\
\hline Staining intensity & $1.8(0.8)[2.0]$ & $2.2(0.8)[2.0]$ & 2.8 & 0.005 & $2.4(0.8)[3.0]$ & 1.4 & 0.17 \\
\hline Total score & $3.6(1.5)[3.0]$ & $4.5(1.9)[5.5]$ & 3.1 & 0.002 & $5.1(1.8)[5.0]$ & 1.8 & 0.07 \\
\hline
\end{tabular}

*Values are mean (SD) [Median]

Table 1: Mean scores of individual parameters according to histopathological stage.

\begin{tabular}{|c|c|c|c|c|c|c|c|c|}
\hline Stage & $\mathrm{N}$ cases & 2 & 3 & 4 & 5 & 6 & 7 & Mean score \\
\hline Early & 101 & 24 & 30 & 26 & 9 & 5 & 7 & $3.6(1.5)$ \\
\hline patch & $(43.0)$ & $(23.8)$ & (29.7) & $(25.8)$ & $(8.9)$ & (4.9) & (6.9) & [3.0] \\
\hline Plaque & $47(20.0)$ & $6(12.8)$ & $6(12.8)$ & $11(23.4)$ & $5(10.6)$ & $8(17.0)$ & $11(23.4)$ & $4.5(1.9)[5.5]$ \\
\hline Nodular & $87(37.0)$ & $13(14.9)$ & $7(8.0)$ & $15(17.2)$ & 10 (11.5) & $16(18.4)$ & $26(29.9)$ & $5.1(1.8)[5.0]$ \\
\hline Total & 235 & $43(18.3)$ & $43(18.3)$ & $52(22.1)$ & $24(10.2)$ & $29(12.3)$ & 44 (18.7) & \\
\hline
\end{tabular}

Table 2: Relative distribution by stages' total histoscore. 
Citation: van Bogaert LJ (2013) Immunostaining by Human Herpes Virus 8 Latent Nuclear Antigen-1 of Kaposi's sarcoma: A Potential Biomarker of Severity of Disease? J Mol Biomark Diagn S5: 002. doi:10.4172/2155-9929.S5-002

having another AIDS-defining illness, CD4+ T-cell counts, and age as prognostic factors [29]. Others used staging at the time of diagnosis, low CD4, and HHV-8 viral load to predict the evolution and the need for chemotherapy [28]. To the best of our knowledge, the histological stage (i.e. early $v s$. late) is not used to determine the therapeutic modalities or the prognosis.

In conclusion, there is overlap between the relative distribution of individual scores of early and late stages of KS. The present findings do not support the use of HHV-8 LANA-1 histoscore as a potential biomarker of progression of KS.

\section{References}

1. Chang Y, Cesarman E, Pessin MS, Lee F, Culpepper J, et al. (1994) Identification of herpesvirus-like DNA sequences in AIDS-associated Kaposi's sarcoma. Science 266: 1865-1869.

2. Pak F, Pyakurel P, Kokhaei E, Kaaya E, Pourfathola AA, et al. (2005) HHV-8/ KSHV during the development of Kaposi's sarcoma: evaluation by polymerase chain reaction and immunohistochemistry. J Cutan Pathol 32: 21-27.

3. Dupin N, Fisher C, Kellam P, Ariad S, Tulliez M, et al. (1999) Distribution of human herpesvirus-8 latently infected cells in Kaposi's sarcoma, multicentric Castleman's disease, and primary effusion lymphoma. Proc Natl Acad Sci USA 96: 4546-4551.

4. Radkov SA, Kellam P, Boshoff C (2000) The latent nuclear antigen of Kapos sarcoma-associated herpesvirus targets the retinoblastoma-E2F pathway and with the oncogene Hras transforms primary rat cells. Nat Med 6: 1121-1127.

5. Pyakurel P, Pak F, Mwakigonja AR, Kaaya E, Heiden T, et al. (2006) Lymphatic and vascular origin of Kaposi's sarcoma spindle cells during tumor development. Int J Cancer 119: 1262-1267.

6. Pyakurel P, Pak F, Mwakigonja AR, Kaaya E, Biberfeld P (2007) KSHV/HHV-8 and HIV infection in Kaposi's sarcoma development. Infect Agent Cancer 2: 4

7. Courville $P$, Simon F, Le Pessot F, Tallet $Y$, Debab Y, et al. (2002) Detection of HHV8 latent nuclear antigen by immunohistochemistry. A new tool for differentiating Kaposi's sarcoma from its mimics. Ann Pathol 22: 267-276.

8. Calonje E (2009) Vascular tumors: tumors and tumor-like conditions of blood vessels and lymphatics; Elder DE (ed.). Lever's Histopathology of the Skin. (10thedn). Philadelphia, Wolters Kluwer, Lippincott Williams \& Wilkins 1007 1056.

9. Grayson W, Panatanowitz L (2008) Histological variants of Cutaneous Kapos sarcoma. Diagn Pathol 3: 31-48.

10. Cheuk W, Wong KO, Wong CS, Dinkel JE, Ben-Dor D, et al. (2004) Immunostaining for human herpesvirus 8 latent nuclear antigen-1 helps distinguish Kaposi sarcoma from its mimickers. Am J Clin Pathol 121: 335-342.

11. Ramirez-Amador V, Martinez-Mata G, Gonzalez-Ramirez I, Anaya-Saavedra G de Almeida OP (2009) Clinical, histological and immunohistochemical findings in oral Kaposi's sarcoma in a series of Mexican AIDS patients. Comparative study. J Oral Pathol Med 38: 328-333.

12. Long E, Llie M, Hofman V, Havet K, Selva E, Butori C, et al. (2009) LANA1, Bcl-2, Mcl-1 and HIF-1alpha protein expression in HIV-associated Kaposi sarcoma. Virchows Archiv 455: 159-170.

13. Kagu MB, Nggada HA, Garandawa HI, Askira BH, Durosinmi MA (2006) AIDSassociated Kaposi's sarcoma in Northeastern Nigeria. Singapore Med J 47: 1069-1074.
14. Morris CB, Gendelman R, Marrogi AJ, Lu M, Lockyer JM, et al. (1996) Immunohistochemical detection of $\mathrm{Bcl}-2$ in AIDS-associated and classical Kaposi's sarcoma. Am J Pathol 148: 1055-1063.

15. Hong A, Lee CS (2002) Kaposi's sarcoma: clinico-pathological analysis of human immunodeficiency virus (HIV) and non-HIV associated cases. Pathol Oncol Res 8: 31-35.

16. Nasti G, Talamini R, Antinori A, Martellotta F, Jacchetti G, et al. (2003) AIDSrelated Kaposi's sarcoma: evaluation of potential new prognostic factors and assessment of the AIDS Clinical Trial Group staging system in the HAART era--the Italian Cooperative Group on AIDS and tumors and the Italian cohor of patients naïve from antiretrovirals. J Clin Oncol 21: 2876-2882.

17. Simonart T, Hermans P, Schandene L, Van Vooren JP (2000) Phenotypic characteristics of Kaposi's sarcoma tumour cells derived from patch-, plaqueand nodular-stage lesions: analysis of cell cultures isolated from AIDS and nonAIDS patients and review of the literature. $\mathrm{Br} J$ Dermatol 143: 557-563.

18. Buonaguro FM, Tomesello ML, Buonaguro L, Satriano RA, Ruocco E, et al. (2003) Kaposi's sarcoma: aetiopathogenesis, histology and clinical features. $J$ Eur Acad Dermatol Venereol 17: 138-154.

19. Phipps W, Ssewankambo F, Nguyen H, Saracino M, Wald A, et al. (2010) Gender differences in clinical presentation and outcomes of epidemic Kaposi sarcoma in Uganda. PLoS One 5: e13936.

20. Gessain A, Duprez R (2005) Spindle cells and their role in Kaposi's sarcoma. Int J Biochem Cell Biol 37: 2457-2465

21. Kennedy MM, O'Leary JJ, Oates JL, Lucas SB, Howells DD, et al. (1998) Human herpes virus 8 (HHV-8) in Kaposi's sarcoma: lack of association with Bcl-2 and p53 protein expression. Mol Pathol 51: 155-159.

22. Kandemir NO, Barut F, Gun BD, Keser SH, Karadayi N, et al. (2011) Lymphatic differentiation in classic Kaposi's sarcoma: patterns of D2-40 immunoexpression in the course of tumor progression. Pathol Oncol Res 17: 843-851.

23. Nickoloff BJ, Griffiths CE (1989) The spindle-shaped cells in cutaneous Kaposi's sarcoma. Histologic simulators include Factor XIIla dermal dendrocytes. Am J Pathol 135: 793-800.

24. Agaba PA, Sule HM, Ojoh RO, Hassan Z, Apena L, et al. (2009) Presentation and survival of patients with AIDS-related Kaposi's sarcoma in Jos, Nigeria. Int J STD AIDS 20: 410-413.

25. Aldenhoven M, Barlo NP, Danders CJ (2006) Therapeutic strategies for epidemic Kaposi's sarcoma. Int J STD AIDS 17: 571-578

26. Altman K, Chang Y (2000) Kaposi's sarcoma. N Engl J Med 342: 1027-1038.

27. Cai Q, Verma SC, Lu J, Robertson ES (2010) Molecular biology of Kaposi's sarcoma-associated herpesvirus and related oncogenesis. Adv Virus Res 78 87-142.

28. Stebbing J, Sanitt A, Nelson M, Powles T, Gazzard B, et al. (2006) A prognostic index for AIDS-associated Kaposi's sarcoma in the era of highly active antiretroviral therapy. Lancet 367: 1495-1502.

29. El Amari EB, Toutous-Trellu L, Gayet-Ageron A, Baumann M, Cathomas G et al. (2008) Predicting the evolution of Kaposi sarcoma, in the highly active antiretroviral therapy era. AIDS 22: 1019-1028.
This article was originally published in a special issue, DNA Diagnosis handled by Editor(s). Dr. George J. Netto, Johns Hopkins University, USA; Dr. Yang Yongliang, Harvard University, USA; Dr. Shahrokh Francois Shariat,

Cornell University, USA 